Meta

Journal des traducteurs

Translators' Journal

\title{
Language Planning and Terminology Planning. Sociolinguistic Aspects
}

\section{Ad Hermans}

Volume 36, numéro 4, décembre 1991

URI : https://id.erudit.org/iderudit/003068ar

DOI : https://doi.org/10.7202/003068ar

Aller au sommaire du numéro

Éditeur(s)

Les Presses de l'Université de Montréal

ISSN

0026-0452 (imprimé)

1492-1421 (numérique)

Découvrir la revue

Citer cette note

Hermans, A. (1991). Language Planning and Terminology Planning.

Sociolinguistic Aspects. Meta, 36(4), 687-689. https://doi.org/10.7202/003068ar
Résumé de l'article

On étudie, d'un point de vue sociolinguistique, les liens entre la planification linguistique et la planification terminologique. On tente de distinguer les aménagements motivés par la défense d'intérêts politiques et ceux visant l'amélioration de la langue. 


\section{LANGUAGE PLANNING} AND TERMINOLOGY PLANNING. SOCIOLINGUISTIC ASPECTS.

Résumé

On étudie, d'un point de vue sociolinguistique, les liens entre la planification linguistique et la planification terminologique. On tente de distinguer les aménagements motivés par la défense d'intérêts politiques et ceux visant l'amélioration de la langue.

Language politics can be defined as the set of decisions guiding a deliberate intervention in language matters. Language planning refers to the implementation of those decisions by solving technical and practical problems.

In order to discuss the relationship between language planning and terminology planning, the following distinctions are useful:

- language planning can be status planning or corpus planning

- language planning can be common language planning or special language planning

- the aim of language planning can be the defense of a political (economic or social) project or the improvement of communication.

Status planning is mostly presented as a solution to a problem. Authorities or governments qualify a situation or a phenomenon as problematic and consider language as an element of strategic value in campaigns promoting overall economic or social values.

Promoting a language as a national (inside a territory) or an official language (with the obligation to use this language in all official documents), 
enforcing the use of a special language in specific social activities or institutions (school, justice, church, press, broadcasting) and recognition of minority languages are the most current interventions on the status of common or special languages. Various language statuses are: official, unique, regional, encouraged, tolerated, discouraged and even forbidden languages. Different measures can be applied: laws, sanctions, propaganda, etc. Education in important acculturation agencies, like schools, is the most common one. Status planning can refer to the language of a whole speech community or to a part of a community.

Status planning sometimes aims at a better communication inside an administrative territory and the integration of a national community. But generally, this practical target hides a more symbolic one: from a sociological point of view the status of a language is one of the means of social control and it determines the access to a number of social positions.

Corpus planning is an intervention on the spelling, syntax or lexicon of a language system. If corpus planning concerns a not yet written language, graphisation and codification are the first operations. Today, most corpus planning campaigns concerning common language are interventions on the spelling of national languages.

Corpus planning of special languages is the task of terminology planning. The aim of terminology planning is (or should be) the improvement of scientific and technical communication. In practice, terminology planning is often an element of status planning and of common language politics.

Most projects relating to language politics and language planning deal with both status and corpus of the language as well as with both common and special languages. Generally the improvement of communication is not the first aim. Terminology planning is often the rationalisation and legitimation of decisions that are taken elsewhere by politicians, and takes part in the power play.

But the study of terminology planning cannot be founded on a theoretical contrast of "improving communication" and "politics." A sociolinguistic approach has to examine the real practice in the real field, i.e. the continuum of communication and politics.

This continuum can be studied at two levels: at the micro-level, inside a scientific or technical community, where terminology of sciences and technology is a product that is negotiated and socially constructed, and at the macro-level of terminology planning and scientific policy.

\section{COMMUNICATION AND STRATEGIES \\ ON A MACRO-LEVEL}

The vocabulary of science and technology is not necessarily rational and should not be seen only as a vehicle for communication, even though that is what it first appears to be and there is no scientific or technical terminology which is not used as a vehicle for communication. Terms are "accomplished facts," they are the result of social interaction. Whether a lexical or syntagmatic unit is a term or not is not a matter of logical or linguistic features.

Such features can only be stated afterwards by linguists. According to terminologists, a term is a lexical or syntagmatic unit defined in specialized texts, irrespective of its linguistic features. "Term" status is thus dependent on the technical or scientific status of the text or speech, which, in turn, depends on the status of the writer, the status of the reader and the status of the circumstances in which the communication takes place.

This status is, like any other social status, the result of recognition, benefits and opportunities. Scientific publications are based on a "gift-giving" principle. The reward for the contribution of an author is not financial but recognition insofar as the reader will adopt the author's terminology.

This terminological ritual is accepted by scientists and laymen because the main purpose of scientific discourse is not to communicate facts and ideas from people who have the scientific information to those people it is intended for, but to keep away from science those people who are not concerned.

Such a ritual is possible if science is considered as the concern of a small group of people, uncommitted searchers after truth, who don't look for their own interests and if scientific knowledge is seen as a step forwards compared to non-scientific knowlerge. Self-seeking and irrational terminological practices are justified by the rational character of scientific endeavour as a whole.

A terminology is thus actively and consciously advertised. Scientific manipulations, such as experimentations, can be seen as an effort to bring terminology into a closer agreement with scientific facts. But the consensus upon a terminology requires that it becomes independent from its creator and gets rooted. Then it may have far-reaching effects: it creates new semantic units, redefines categories, organizes phenomena, generates concrete or abstract objects and determines major issues.

\section{TERMINOLOGY AND POLITICS}

According to the traditional ethos of science, there is a complete separation of science and politics. Scientists are obeying the imperatives of scientific logic and protect themselves from political interference. Science belongs to the field of possibilities, politics determines choices inside the field of possibilities.

This distinction between science and politics is a cultural one which enables two different processes. In the first place, it enables certain matters to be defined as scientific in order to protect them from the variability of the political power play. In this 
way, important social issues can be pulled away from political interests. But scientific arguments become, later on, political instruments to influence the distribution of power. This happens namely when "the one best scientific way" corresponds to the "way" that is chosen by politicians for non-scientific reasons. The fact that a reality is a scientific one becomes a serious argument in the political game.

The need for funding makes scientific work more and more dependent on an explicit science policy where political objectives are more important than scientific needs. Scientific and technological development is institutionalised and the direction of scientific development depends on public investment and political decisions.

Scientific terminology therefore fits into political and administrative categories. It is rooted in the soil of existing ideas and affected by the dominance of a particular social sector. For example, during the steam engine era, the concept of energy generated a new terminology in several sciences. Nowadays, the concept of "information" is generating a series of related terms in several disciplines. Science operates within the conceptual framework of the social and political community it belongs to.

Terminological strategies also take public opinion into account. The public is more acutely aware, today, of the negative impact of scientific and technological progress (genetic engineering, nuclear technology) and of the huge investments required by scientific endeavour, which scientists are called upon to validate. Hence, terminologies have more charisma then, while rationality is questioned.

Terminologies are therefore subject to, both voluntary and involuntary change. Terminologies, gradually and unintentionally, shift the conceptual system in which they are produced.

Even the consequences of an active terminology planning cannot be foreseen. International scientific and technical communication is not only a technical process but also a social one. Characteristics of international and national special language are independent of the status of a particular common national language.

Special language has its own evolution and is committed to social and linguistic constraints that differ from those of common languages. Major social implications are: processes of identification with the scientific community, acculturation, delimitation of a (new) science, budgets, personnel, prestige, recognition.

Terminology planners have to cope with the opposition between statistical dominant usage and prestige usage, language rituals and pro domo terminology.

Usage will always undermine norms and the situation of scientific communication has to be analysed in terms of relations of force.

\section{BIBLIOGRAPHY}

DE MEY, M (1987): "Can cognitive structure be reduced to social force?" in Gosselin $M$. and Demeyer F (eds.), Science and Society, Bruxelles.

DE SCHAETZEN, C (Réd.) (1989): Terminologie diachronique, Centre de terminologie de Bruxelles/CILF, Bruxelles, Paris.

HAGSTROM, W.O. (1972): "Gift-Giving as a Organizing Principle is Science," in Sociology of Science, Middlesex.

JACOBI, D. (1984) : «Du discours scientifique, de la reformulation et de quelques usages sociaux de la science», in Langue française, décembre 1984.

LATOUR, B. (1989): La science en action, Paris.

ROSENBERG, C.E. (1972): "Scientific Theories and Social Thought," in Sociology of Science, Middlesex.

STENGERS, I et J. SCHLANGER (1989): Les concepts scientifiques, Paris.

Ad HERMANS Centre de terminologie de Bruxelles 